\title{
Islamic Indigenous Versus Islamic Puritanism in Adiraja Village, Adipala District, Cilacap Regency Central Java Indonesia
}

\author{
Nawawi \\ \{nawawi.sirau@gmail.com\} \\ State Islamic University Prof. K.H. Saifuddin Zuhri (UIN SAIZU) \\ Purwokerto Central Java Indonesia
}

\begin{abstract}
The conflict between Islamic Indigenous and Islamic Puritanism in Adiraja Village is a conflict of views between two communities that live together in one area. These differences in views lead to stereotypes of social interaction and tension in society. The focus of this study is how the conflict between Islamic Indigenous and Islamic Puritanism in Adiraja Village, Adipala District, Cilacap Regency. The research method used is a qualitative research method with a phenomenological approach. The results show that there are contradictions between Islamic Indigenous and Islamic Puritanism, namely Wetan Dalan Versus Kulon Dalan, Gusti Ingkang Makaryo Jagad Versus Allah SWT, the Turkish Book Versus the Qur'an, Manembah versus Prayer, Reject Bala Versus Sacrifice.
\end{abstract}

Keywords: Islamic Indigenous; Islamic Puritanism; Conflict

\section{Introduction}

Religious life in Adiraja Village, Adipala District, Cilacap Regency. Socially, the life of the Adiraja people looks harmonious and harmonious, but if you look closely, they have problems and tensions between them. This is triggered by their different beliefs. Statistically, the majority of Adiraja people are Muslim, but some people have a different Islamic style from others, some are adherents of Indigenous Islam and some are Puritan Muslims. Adherents of their Indigenous Islam have a unique belief system. The strength and uniqueness of their belief system so that they display distinctive religious patterns and expressions (Kadir, 2018: 61). Indigenous Islam is one of the products of dialogue between Islam and local culture whose existence is still strong (Partokusumo, 2018:162). The Indigenous Islamic belief system adheres to the kejawen belief. The Indigenous Islamic Community has special characteristics that become its identity in daily appearance that is different from the surrounding community. This identity shows their character and equipment in accordance with the teachings of Indigenous Islam which they maintain from time to time. One of the characteristics of the Indigenous Islamic community is the symbol of group identity(Bahtiar and Rahman, 2018: 162) which can be seen in terms of clothing that is different from other communities which are usually worn during ritual activities. The male followers wear batik sarongs and black clothes 
with blangkon as head coverings and the women use kebaya or kemben, an ancient Javanese dress model (Wahyu et al, 2013:66).

It is different with adherents of Islamic Indigenous, the residents of Adiraja Village who adhere to Islamic Puritanism, they are consistent with Islamic teachings (Han, E.S \& Goleman, 2019: 73) namely Islamic teachings based on the Qur'an and Hadith as taught by the Prophet Muhammad. They say the two sentences of creed, perform the obligation of prayer, pay zakat, fast in the month of Ramadan and perform Hajj for those who can afford it. They carry out Allah's commands and stay away from His prohibitions. They also perform amar makruf nahi munkar which is an obligation for Muslims to call, remind, and invite to the right path that is blessed by Allah swt.

Regarding what the adherents of Indigenous Islam do in their lives, according to the views of the adherents of Puritan Islam, it is not in accordance with the true teachings of Islam. Their Islam is just a confession. They also often performed rituals of life which, according to the Puritans, were against the teachings of Islam. All of these in the view of the Puritans are forms of deviation that must be corrected, both in their beliefs and forms of worship. Therefore, the conflict and tension between the two occurred. From this phenomenon, the author is interested in knowing more about the conflict between Indigenous Islam and Puritan Islam in Adiraja Village, Adipala District, Cilacap Regency, Central Java, Indonesia.

This study uses qualitative research methods with a phenomenological approach (Hodgetts, Darrin and Kerry Chamberlain, 2014: 245). Qualitative research methods based on phenomenology require a holistic approach, placing the object of research in a dual construction, seeing the object in a natural context (Satori and Komariah, 2011: 78). The subjects in this study were four Indigenous Muslims and four Puritan Muslims who were selected based on the magnitude of their role in society and their knowledge of conflicts between communities and their role in the Adiraja Village community. Data collection techniques used are observation, interviews and documentation. Data analysis techniques include four things, namely data collection, data reduction, data presentation, and drawing conclusions or verification.

\section{Results and Discussion}

Ferret, J \& Collin, R, (2018) One of the causes of conflict is a wrong world view or vision de monde. In fact, it is very important to direct life. Fajarini (2014) argues that the occurrence of spiritual pathology or spiritual illness in modern humans is more due to orientation errors in living life. Thus, continuous enlightenment is needed in designing a quality life orientation, a form of life that is full of harmony, maintaining the spirit of diversity. The conflict between Islamic Indigenous and Islamic Puritan in Adiraja Village, Adipala District, Cilacap Regency is as follows:

\section{a) Wetan Dalan Versus Kulon Dalan}

Geographically, Adiraja Village consists of 13 hamlets spread over the Adiraja Village area and part of the rice fields. There is one hamlet which is split into two parts, namely Adiraja hamlet which is split by a highway into two parts, namely the East and West. The Wetan (East) part of the area is the center of Indigenous Islam as said by Kayim Ahmad Sumedi " Menawi wetan dalan menika sedaya tiang Islam Adat, lan pusate gih teng mriku”" (If the east side of the road, all adherents of Indigenous Islam, the center is there). The citizens of 
the community all adhere to Indigenous Islam. In that place there is a ritual place for the Indigenous Muslim community. His name is Pasemuan. In the Kulon Dalan section (west of the road) which is the opposite of Wetan Dalan, the majority of the people are Puritan Muslims. Here there is a large mosque called the Baiturrahman Mosque and six prayer rooms as a place of worship for members of the Puritan Islamic community. They practice Islamic teachings in accordance with the guidance of the Prophet Muhammad and based on the Qur'an and Hadith. Baiturrahman Mosque as the center of the activities of the Adiraja Muslims.

\section{b) Gusti Ingkang Makaryo Jagad Versus Allah SWT}

There are fundamental differences that cannot be reconciled between Indigenous Islam and Puritan Islam, especially the notion of God / Gusti Ingkang Makaryo Jagad (Fahrurrozi, 2014: 39) The view of God according to Indigenous Muslims is that God is Merciful, so it is impossible to make hell to punish humans because Indigenous Islam only recognizes God's law as natural law, the law of cause and effect is the same as the law of karma in Hinduism but only applies in the world. Adherents of Indigenous Islam believe in the Supreme Essence but the way to achieve it is believed not to have to follow Puritan Islam. Indigenous Muslims consider themselves to be Muslims by simply reading the creed when married at the Office of Religious Affairs (KUA). without having to do as the Puritans did. (Permana, 2010: 69). The Puritan Islamic view of God which is called Allah is very contrary to the view of Indigenous Islam. According to Haji Idris, Allah, in the view of Puritan Islam, is the One and Only Essence, the Almighty, the Most Great, the All-Powerful and there is no one like him. Allah must be believed, He is the One who creates, gives life, turns off, and gives sustenance. Allah is the one who oversees, regulates, controls the universe and everything in it, the owner of the law and others of everything that shows the sole authority for Allah. Allah made heaven and hell, heaven for recompense for those who obey and carry out Allah's commands, while hell is for recompense for those who disobey Allah. From here, a believer must believe that no one can match Allah, must obey all His commands and stay away from all His prohibitions. Haji Idris more explicitly mentions in the Qur'an Surah Al Ikhlas verses 1 to 4 which means: "'Say!' $\mathrm{He}$ is God Almighty. Allah is a God who depends on Him all things. He was childless and not begotten. And no one is equal to Him.

\section{c) Turkish Book Versus Al Qur'an}

In the Indigenous Islamic community in Adiraja, there is a way of life called the Turkic book. This book is not a written book but an unwritten book. This Turkish book is also not a book that originated in Turkey. The Turkish name is an abbreviation of the word "Tuturing kaki (advice of ancestors). The Indigenous Muslim community in Adiraja even though they claim to be Muslim, they do not know the book of the Qur'an which is a way of life for Muslims around the world. Indigenous Islamic communities adhere to the Turkic books or tales of the feet (advices of their ancestors) in living their lives. For example, in determining their leader based on lineage, especially descendants from the male side. Their leader is called Bedogol (Sham, 2018: 80).

The Qur'an was revealed by Allah to be a guide for human life, the difference between right and wrong, right and wrong, good and bad. Therefore, the Qur'an must be used as a guide for life. For that, faith in the Qur'an must be totality. The Koran as a way of life requires Muslims to take and implement the provisions and laws given by the Koran, namely Islamic sharia laws. Because the Qur'an also commands Muslims to take whatever the Prophet brought 
and leave what he forbade. Haji Abdullah quoted the verse of the Qur'an Surah Taha verse 124, which means: So if guidance comes to you from Me, then whoever follows My guidance, he will not go astray and will not be harmed. And whoever turns away from My remembrance, then indeed for him is a narrow life.

\section{d) Manembah Versus Prayer}

Manembah comes from the word worship which means to offer something. Indigenous Muslim communities have various ways of worshiping (worshipping God). For the Indigenous Muslim community, there are no specific provisions or ways to worship Gusti Allah. In performing manembah, there are four levels of panembah. This is explained by Mr. Sumitro as follows: Samengko ingsun tutur, Sembah catur supaya lumuntur, Dhihin raga cipta jiwa rasa karsa, Ingkono lamun ketemu,Tandha nugrahaning Manon (I explain the four kinds of worship now, namely worship of body, worship of creation, worship of the soul and worship of taste. But for Puritan Muslims, praying is not offering something to Allah, but instead asking, there is no offering. Praying for a Muslim is an obligation. Whoever abandons prayer is a disbeliever. Prayer is also the difference between disbelief and faith. Adherents of Indigenous Islam in the view of Puritan Muslims are infidels because they do not perform prayers as directed in the Qur'an and Hadith. They are also seen as partners with Allah because in their rituals they offer something not to Allah but to the spirits of their ancestors.

\section{e) Reject Bala Versus Sacrifice}

Indigenous Muslim communities they usually slaughter animals that are offered to the spirits of their ancestors. The goal is to protect them from harm. Residents who work as fishermen, they do sea rafting which is dedicated to the rulers of the South Sea to be given safety, protected and given a lot of sustenance while at sea. For the farming community, they also offer offerings to Dewi Sri (Pranowo, 2009: 119). rulers and guards of their fields so that their rice crops are safe from all pests and diseases. In every ritual they always slaughter a goat or cow. All these slaughters are cooked together. The cooks are all male. In this case there is something very unique according to the author, during the cooking process no one dares to taste the food, let alone eat it. Why is that ? it turns out that all the meat dishes are for offerings to their ancestors so that no one should precede them. In the view of Puritan Muslims, this ritual of rejecting reinforcements is undoubtedly shirk, because slaughtering animals for sacrifice is worship, and worship cannot be offered except to Allah. Haji Abdullah asserted "Verily my prayer, my sacrifice (my sacrifice), my life and my death are only for Allah, the Lord of the worlds, there is no partner for him". It is strengthened by the Hadith of the Prophet "And Allah curses those who slaughter for other than Him." In the view of Indigenous Muslims, the sacrifices made by Puritan Muslims on Eid al-Adha are not worship because it is for humans not for God. The difference in views between the two causes tension between them.

\section{Conclusion}

In general, the conflict between Islamic Indigenous and Islamic Puritan appeared to arise due to existing social interactions, identity values, religion, and structural domination. In relation to the value of identity and religion as a source of conflict, including the dimension of 
primordial conflict, namely conflict as a result of shifting interests of ethnic or religious-based identity groups. Observing this, social conflicts in Adiraja society can be caused by several factors, such as: First, differences in individual attitudes or feelings. Second, differences in cultural backgrounds so as to form different individuals. Differences in cultural values have the potential to cause conflict. The cultural values of Indigenous Muslims are very different from those of Puritan Muslims. Differences in culture and values of life are more visible when people's interactions become easier. Third, differences in interests between individuals or groups, whether political, economic, social, cultural or religious, also have the potential for conflict. Fourth, rapid and sudden value changes in society.

The conflict between Indigenous Islam and Puritan Islam is a hostile feeling (aggressiveness or hostility) that exists latent in humans. However, hostile feelings do not necessarily cause open conflict (covert conflict). Open conflict can occur in addition to hostile feelings, as well as hostile behavior (hostile behavior) in society. The conflict between Indigenous Islam and Puritan Islam is a realistic and non-realistic conflict. Realistic conflicts come from concrete, more material things, such as the struggle for economic resources or territory. Meanwhile, non-realistic conflicts are driven by desires that tend to be ideological in nature, beliefs and beliefs.

\section{References}

[1] Abimanyu, Petir 20014 Mistik Kejawen, Yogyakarta: Palapa

[2] Bahtiar, Ahmad dan Rahman, 2018 Konflik Agama Dalam Novel Maryam Karya Okky Madasari, Jentera : Jurnal Kajian Sastra Volume 7 No 2.

[3] Barati Bagherabad, T. (2018). Towards relational becoming! an investigation on conflict narratives.(Universityof https://doi.org/https://doi.org/10.3990/1.9789036544764

[4] Fajarini, U. (2014). Potret Konflik Keagamaan Masyarakat Tangerang Banten dan Resolusi Konflik Berbasis Multikulturalisme dalam Islam. Al-Tahrir: Jurnal Pemikiran Islam. https://doi.org/10.21154/al-tahrir.v14i2.76

[5] Fahrurrozi, 2014 Konflik Agama dan Etika Dialog: Membaca Dialog Kemanusiaan dalam Bingkai Sosiologi Komunikasi, Tasamuh:Volume 12, No.1.

[6] Ferret, J., \& Collins, R. (2018). On the Internal Dynamics of the Conflict/Violence Process: A Discussion with Randall Collins. American Sociologist. https://doi.org/10.1007/s12108-017-9346-0

[7] Han, E. S., \& goleman, daniel; boyatzis, Richard; Mckee, A. (2019). Politik Identitas dan Gerakan Sosial Islam (Studi atas Frot Pembela Islam). In Journal of Chemical Information and Modeling.

[8] Huda, M. (2018). The Negotiating Process Of Ponorogo's People Toward Prohibitions In Javanese Marriage Tradition. Al-Risalah, 17(01), 87-103.

[9] Hodgetts, Darrin and Kerry Chamberlain. 2014. "Analysing News Media." in The Sage Handbook of Qualitative Data Analysis, ed. U. Flick. Sage Publications.

[10] Kadir, A. (2018). Merawat Kerukunan Toleransi di Ero Demokrasi. ASKETIK. https://doi.org/10.30762/ask.v2i2.872

[11] Khasan, B. I. (2015). An Experience of Applied Conflictology. Journal of Siberian Federal University. Humanities \& Social Sciences. https://doi.org/10.17516/19971370-2015-8-11-2789-2797

[12] Maria, I. M., \& Arta, M. (2017). Albania and the teaching of religion in schools. 
Academicus International Scientific Journal. https://doi.org/10.7336/academicus.2017.15.01

[13] Masvaure, S. (2018). Decentralisation: unshared vision and political contestation in the City of Harare, Zimbabwe. Journal of Political Power. https://doi.org/10.1080/2158379X.2018.1477375

[14] Nurdin, M. A. (2019). Kajian Multikulturalisme dan Kaitannya dengan Kerukunan. Refleksi. https://doi.org/10.15408/ref.v18i1.12690

[15] Partokusumo, Karkono Kamajaya, 1995 Kebudayaan Jawa Perpaduannya dengan Islam, Yogyakarta: Aditya Media.

[16] Permana, Yogi Setya 2010, Kontestasi Abangan-Santri Pasca Orde Baru di Pedesaan Jawa, Jurnal Ilmu Sosial dan Ilmu Politik :Volume 14, No. 1.

[17] Pranowo, Bambang 2009 Memahami Islam Jawa, Jakarta: Pustaka Alvabert.

[18] Putra, A. E. (2015). Penyerbukan Silang Antarbudaya Menurut Eddie Lembong (suatu Perspektif Tasawuf). Al-Adyan: Jurnal Studi Lintas Agama, 10(2), 272-282.

[19] Rahmawati, D. E., Darwin, M., \& Ahmad, M. (2018). Power Contestation on Marriage Age Discourse in dealing with Islamic Values: A Case Study on Nahdlatul Ulama. Jurnal Studi Pemerintahan, 9(1), 83-112.

[20] Rozin, M., Prawoto, S., Setiawan, F. N., \& Rosita, N. (2020). Recontextualization in the Indonesian Translation of the Novel "Taj": A Story of Mughal India" by Timeri N. Murari. https://doi.org/10.2991/assehr.k.200306.012

[21] Satori, Djam'an dan Komariah, Aan 2011 Metodologi penelitian kualitatif Bandung : Alfabeta

[22] Shashangka, Damar 20014 Induk Ilmu Kejawen Wirid Hidayat Jati, Jakarta : Dolphin

[23] Suyono, Capt. RP, 2007 Dunia Mistik Orang Jawa, Yogyakarta: LkiS

[24] Syam, Syamsuar 2018 Mengenal Islamisasi di Nusantara: Konflik dan Akomodasi (Kajian Tentang Proses Penyebaran Islam Periode Awal di Nusantara), Al-Hikmah: Volume 12, No. 1

[25] Terhalle, M., \& Depledge, J. (2013). Great-power politics, order transition, and climate governance: insights from international relations theory. Climate Policy. https://doi.org/10.1080/14693062.2013.818849

[26] Wahyu, Anindya dkk 2013 Interaksi Masyarakat Komunitas Islam Blangkon dan Komunitas Muhammadiyah di Desa Pekuncen, Kecamatan Jatilawang, Kabupaten Banyumas, Solidarity Volume 13, No 2.

[27] Wiener, A. (2017). Constitution and contestation of norms in global governance: A cycle model. In Presentation at the Departmental Seminar in Political Science and International Studies (POLIS). University of Cambridge (Vol. 8).

[28] Woordward, Mark 1999 Islam Jawa: Kesalehan Normatif Versus Kebatinan, Yogyakarta: LKiS 